\title{
Effects of Tunicamycin on the Proliferation, Adhesion and Differentiation of Chick Embryo Chondrocytes in Clonal Cell Cultures
}

\author{
Kazuo Watanabe, Gakuzo Tamura* and Hiromi Mitsui** \\ Kanebo Institute for Cancer Research, 1-9-1, Misakicho, Hyogo-ku, Kobe 652, \\ Japan, *Department of Agricultural Chemistry, The University of Tokyo, \\ Bunkyo-ku, Tokyo 113, Japan, **The Tokyo Metropolitan Institute of Medical \\ Science, Bunkyo-ku, Tokyo 113, Japan
}

\begin{abstract}
The effects of tunicamycin, a specific inhibitor of lipid-carrier dependent glycosylation of protein, on the proliferation, adhesion, and differentiation of freshly liberated chondrocytes from chick embryos were studied in clonal cell cultures. Incubation of cells with a high dose of tunicamycin (more than $30 \mathrm{ng} / \mathrm{ml}$ ) caused complete inhibition of cell division. When tunicamycin was removed after a 5-day exposure in culture, cells immediately started to divide synchronously. The cloning efficiency was higher, and colony size was more regular than in the control culture. Tunicamycin interferred with the adhesion of the cells to the plastic substratum at a low dose (less than 3 $\mathrm{ng} / \mathrm{ml}$ ), and the number of attached cells decreased as the concentration of tunicamycin increased. However, at a higher dose (more than $30 \mathrm{ng} / \mathrm{ml}$ ), all the cells adhered to the substratum. Different mechanisms of cell adhesion may operate for low and high does of tunicamycin. Formation of the cartilage matrix was not inhibited in so far as the cells proliferated to form colonies.
\end{abstract}

Although increasing attention has been paid to cell surface glycoproteins $(10,12$, 21) which are believed to play important roles in regulating the social behaviors of cells, many problems, especially the function of carbohydrate moieties in glycoproteins, have yet to be solved.

We have examined the influence of tunicamycin, an antibiotic that inhibits protein glycosylation, on the behavior of chick embryo chondrocytes in primary clonal cultures. Tunicamycin inhibits the synthesis of N-acetyl-glucosaminyl pyrophosphoryl polyisoprenol $(13,16)$. Since this reaction is involved in the synthesis of the core sequence for $\mathrm{N}$-glycosidically linked oligosaccharides, tunicamycin treatment results in a deficiency of asparagine-linked oligosaccharides (15), in the synthesis of glycoprotein.

Primary clonal culture of chondrocytes from chick embryonic sterna was used because the system has many advantages over other primary cell culture systems. First, a large homogeneous cell population is available. Second, the technique for in vitro cultivation at lower cell density has been well-established $(1,18)$. And third, modifications of in vitro cellular behavior, including anchorage dependence of cell growth, the expression of differentiative traits, etc., can be easily conducted under controlled conditions $(8,19,20)$. 
We here describe the unique characteristics of chick embryo chondrocytes revealed by tunicamycin treatment.

\section{MATERIALS AND METHODS}

Cell culture. Sterna were taken from 13-15 day old chick embryos, and treated with $0.25 \%$ trypsin (Difco, 1: 250) for $40 \mathrm{~min}$. The softened tissue pieces were dissociated by pipetting them up and down in a Pasteur pipette. The dissociated cells were washed with Hanks's solution, then filtered through fine silk mesh to remove undissociated cell masses after which they were counted. A cell suspension of $5 \times 10^{3} \mathrm{cells} / \mathrm{ml}$ was prepared, and 0.2 $\mathrm{ml}$ of this suspension (1,000 cells) was inoculated in a $50 \mathrm{~mm}$ Falcon plastic culture dish with $3 \mathrm{ml}$ of culture medium. The dishes were incubated at $37^{\circ} \mathrm{C}$ in a humidified $5 \% \mathrm{CO}_{2}-95 \%$ air incubator. The composition of the culture medium was 92 parts Ham's F-12 (modified, powder, Flow lab., U.S.A.), 8 parts fetal bovine serum (GIBCO, U.S.A.), and $0.14 \mathrm{gr} / \mathrm{ml}$ of $\mathrm{NaHCO}_{3}$. Two milliliters of the culture medium was added on the 3rd day. Thereafter, a medium change was carried out every other day.

Tunicamycin. Tunicamycin was dissolved in methanol at a concentration of $1 \mathrm{mg} / \mathrm{ml}$. It was further diluted with Dulbecco's balanced salt solution to $100 \mu \mathrm{g} / \mathrm{ml}$ (stock solution). Serial dilution was made from the stock solution, and $0.1-0.2 \mathrm{ml}$ of the final dilution was added to the culture medium.

\section{RESULTS}

Effects of tunicamycin on cell division. The rate of cell division was measured by counting the cell numbers of the growing colonies on the 5 th day of cultivation. Fig. 1. shows that $100 \mathrm{ng} / \mathrm{ml}$ of tunicamycin completely blocks cell division. At $30 \mathrm{ng} / \mathrm{ml}$, cell division was also strongly retarded, although one or two divisions occasionally took place, but no more cell division took place (Table 1). At the concentration of $3 \mathrm{ng} / \mathrm{ml}$, cell proliferation progressed as in the control cultures (Fig. 1, Table 1).

Recovery from the drug effect. Removal of tunicamycin $(100 \mathrm{ng} / \mathrm{ml})$ from the culture medium after 5 days of cultivation, produced cell proliferation, and almost the same number of colonies existed on the 12th day after the removal as in the controls (Table 1).

Interestingly, when cell division was blocked by $30 \mathrm{ng} / \mathrm{ml}$ of tunicamycin for 5 days, the number of colonies after its removal increased 1.5 fold. In this case, we noticed a tendency for synchronous cell division in the early phase of clonal growth in a colony or among colonies. The size distribution of the resulting colonies was fairly uniform and gave a narrow peak at $0.55 \mathrm{~mm}$ (Fig. 2), which differed from the tunicamycinfree control cultures, in which colony size was distributed rather broadly.

Even when cells had been kept from dividing for 11 days by extending the period of tunicamycin blockage (Table 1), a considerable number of colonies (54 colonies from 1,000 cells) developed, after the removal of tunicamycin.

Effects of tunicamycin on the anchorage of cells to the plastic substratum. The growth in vitro of cartilage cells is known to be anchorage-independent $(8,20)$. Under our culture conditions, $83 \%$ of the cells anchored to the substratum on the 5 th day, most of which had spread onto the substratum (Fig. 3a). The remaining population $(16 \%)$ had round shapes and did not adhere to the substratum. These cells also grew repidly in the suspension (Fig. 3b). 


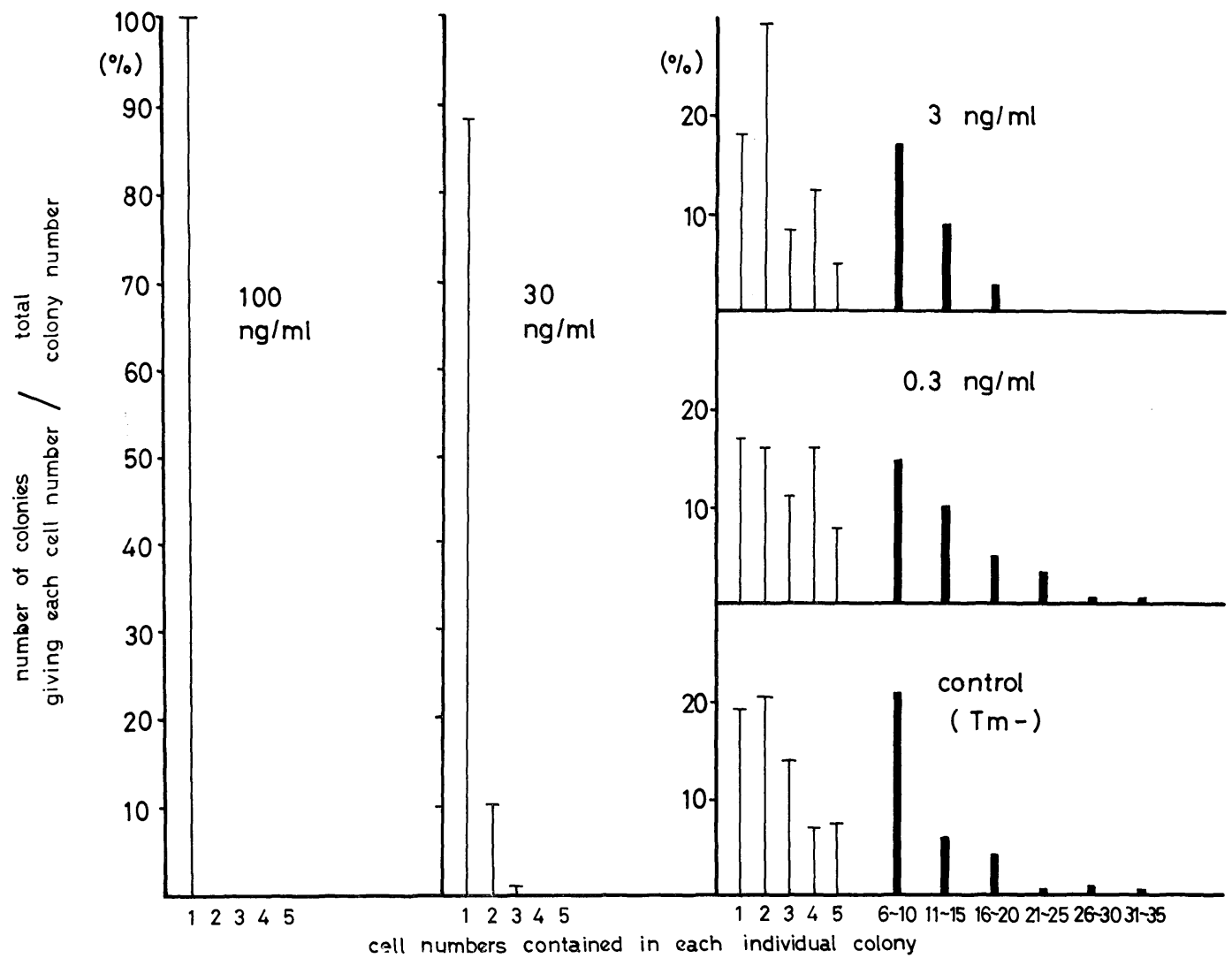

Fig. 1. Effects of tunicamycin on the colonical growth of single chondrocytes. Data shows the distribution frequency of cell numbers in each colony, assayed on the 5th day of cultivation. At least 500 living colonies were checked by phase-contrast microscopy.

TABLE 1. RECOVERY FROM THE DRUG EFFECT

\begin{tabular}{|c|c|c|c|c|c|c|c|c|}
\hline & \multirow{2}{*}{$\begin{array}{l}\text { Total } \\
\text { culture } \\
\text { period } \\
\text { (day) }\end{array}$} & \multicolumn{7}{|c|}{ Concentration of tunicamycin $(\mathrm{ng} / \mathrm{ml})$} \\
\hline & & 0 & 1,000 & 300 & 100 & 30 & 3 & 0.3 \\
\hline $\begin{array}{l}\text { tunicamycin }(-) \\
\text { throughout }\end{array}$ & 12 & $289 \pm 12^{\mathrm{b}}$ & & & & & & \\
\hline $\begin{array}{l}\text { tunicamycin }(+) \\
\text { throughout }\end{array}$ & 12 & & 0 & 0 & 0 & 0 & $268 \pm 37$ & $225 \pm 24$ \\
\hline $\begin{array}{l}\text { removed } \\
\text { at } 5 \text { th day }\end{array}$ & 17 & & 0 & $101 \pm 11$ & $280 \pm 22$ & $448 \pm 24$ & $(272)^{c}$ & - \\
\hline $\begin{array}{l}\text { removed } \\
\text { at } 8 \text { th daya }\end{array}$ & 20 & & - & - & - & $315 \pm 31$ & - & - \\
\hline $\begin{array}{l}\text { removed } \\
\text { at } 11 \text { th day }\end{array}$ & 23 & & - & 0 & $(3)^{c}$ & $54 \pm 31$ & - & - \\
\hline
\end{tabular}

a Each dish was cultured for 12 days after the removal of tunicamycin.

b Each dish was inoculated with 1,000 cells per dish. Data shows the average number of colonies from 5 dishes. The count was made after fixation and staining with toluidine blue.

c ( ) means data from one dish. 


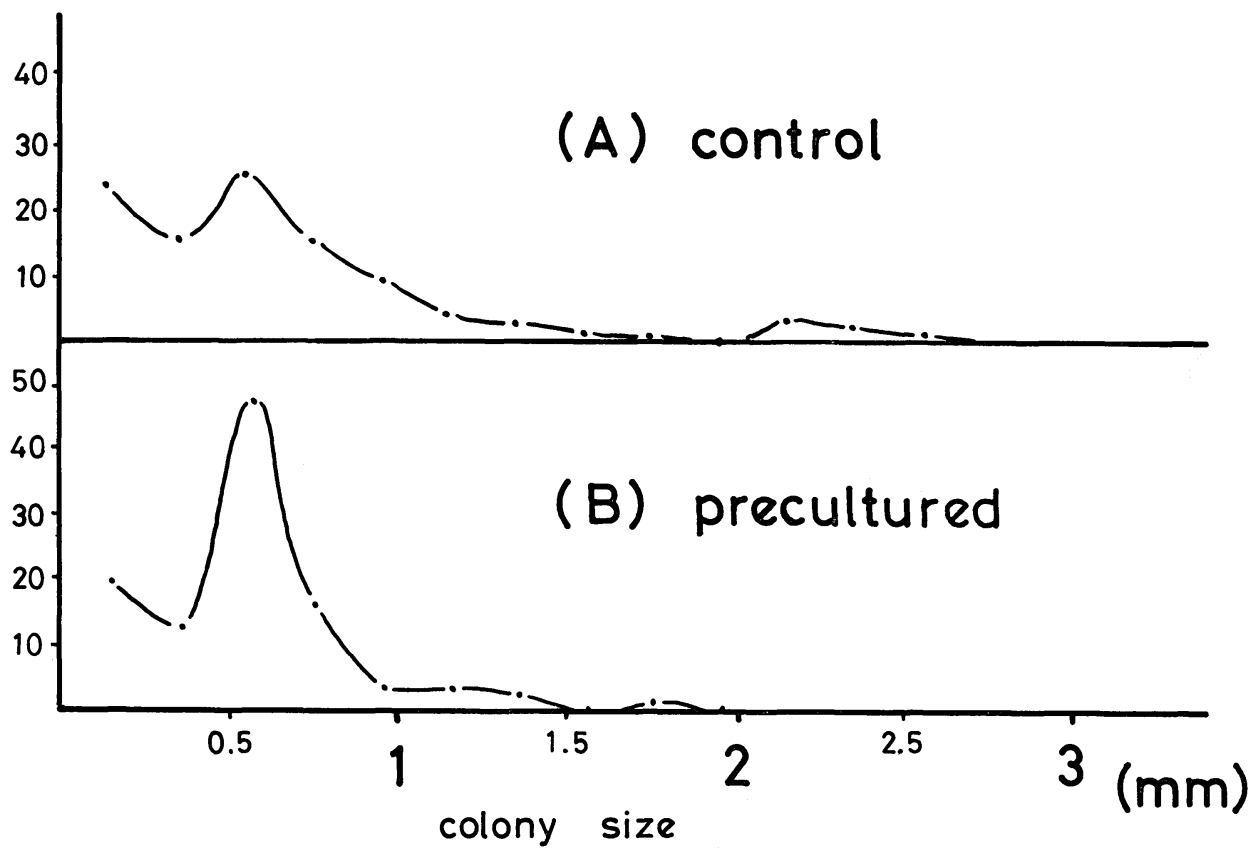

Fig. 2. Effect of precultivation with tunicamycin on colony size. After cells had been cultured with $30 \mathrm{ng} / \mathrm{ml}$ of tunicamycin without cell division) for 5 days, they were washed and cultured again for 12 days without the drug. The colonies obtained were fixed, then their diameters were measured, and the size distribution calculated (B). Control (A) shows data obtained from the 12-day cultivation period only. At least 500 colonies were measured.

TABLE 2. EFFECTS OF TUNICAMYCIN ON CELL ADHESION TO THE SUBSTRATUM, WITH SCHEMATIC REPRESENTATION OF THE RELATIONSHIP BETWEEN CONTACT BEHAVIOR AND THE

\begin{tabular}{|c|c|c|c|c|c|}
\hline \multicolumn{5}{|c|}{ PROLIFERATING ACTIVITY OF THE CELLS } & \\
\hline $\begin{array}{l}\text { Concentration } \\
\text { of tunicamycin } \\
(\mathrm{ng} / \mathrm{ml})\end{array}$ & 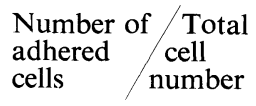 & $\%$ & $\begin{array}{l}\text { Proliferating } \\
\text { activity }\end{array}$ & $\begin{array}{l}\text { Cell shape and } \\
\text { relation to } \\
\text { substratum }\end{array}$ & \\
\hline 0 & $902 / 1093^{a}$ & 83 & + & $\begin{array}{l}\text { spread on the } \\
\text { substratum }\end{array}$ & $\sqrt{03}$ \\
\hline 0.3 & $827 / 1167$ & 71 & + & $\downarrow$ & $\downarrow$ \\
\hline 3 & $284 / 878$ & 32 & + & floating & 0 \\
\hline 300 & $108 / 108$ & 100 & - & $\begin{array}{l}\text { firmly } \\
\text { adhered to the } \\
\text { substratum } \\
\text { without } \\
\text { spreading }\end{array}$ & $\frac{\Omega}{\| \prime \prime I I I ~}$ \\
\hline
\end{tabular}

a Data shows the "number of cells adhering to the substratum per total cell number in the culture", counted on the 5th day of cultivation. All the cells anchored to the plastic substratum were counted as "adhered", regardless of whether they had "spread or not". Counting was made directly on living cultures by phase-contrast microscopy. 

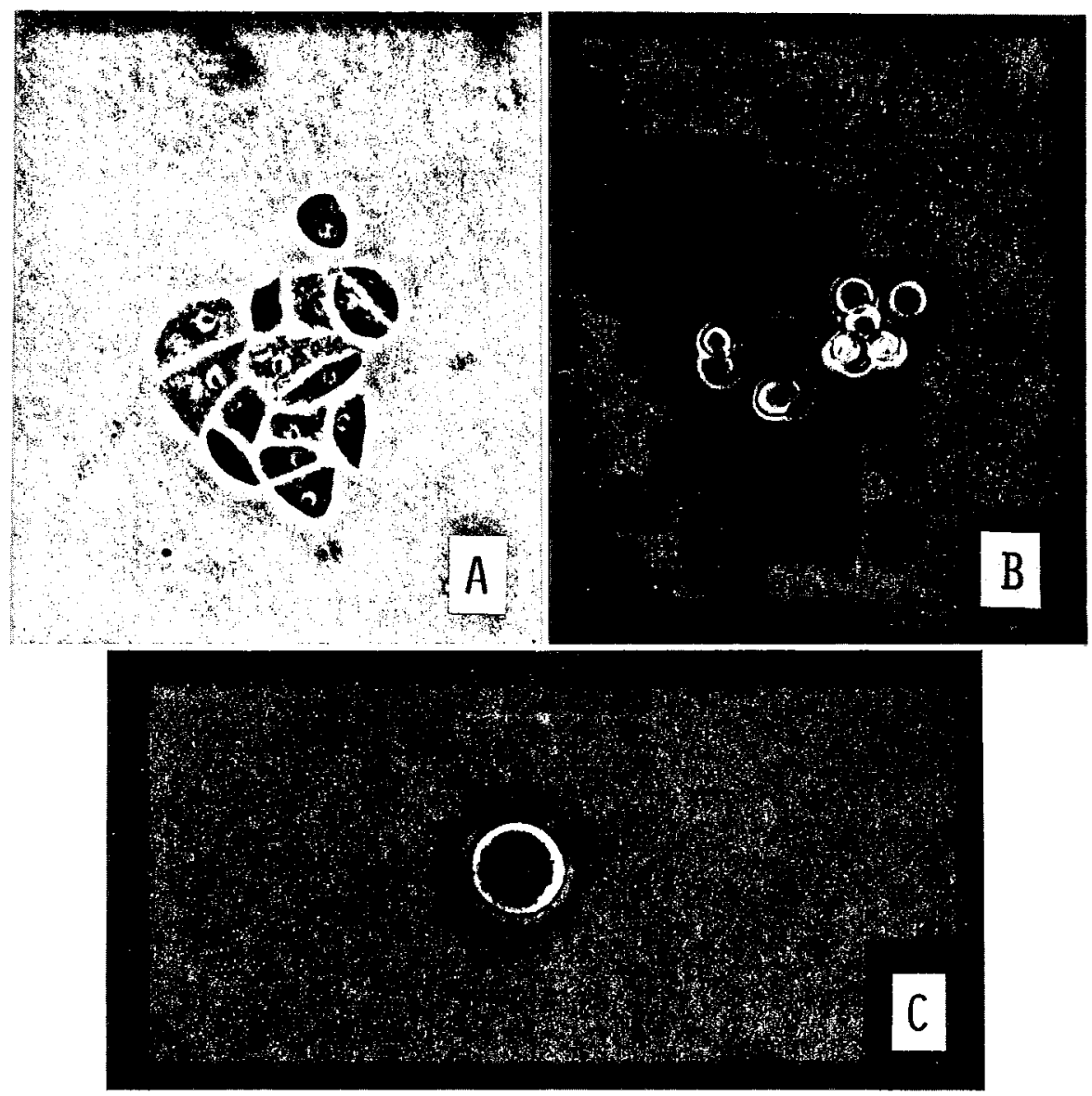

Fig. 3. Chondrocytes on the 5th day of cultivation. (A) shows a colony consisting of adhering and spreading cells. (B) shows a colony consisting entirely of floating cells. (C) shows a single cell, firmly adhering to the substratum without cell division in medium containing $30 \mathrm{ng} / \mathrm{ml}$ of tunicamycin. Phase-contrast micrographs. (A) and (B) $\times 300,(C) \times 600$

At the concentration of $0.3 \mathrm{ng} / \mathrm{ml}$ tunicamycin, $29 \%$ of the population floated; at $3 \mathrm{ng} / \mathrm{ml}$, this figure became $68 \%$ (Table 2). Rather unexpectedly at a concentration of $30 \mathrm{ng} / \mathrm{ml}$ or higher, when cell division was strongly retarded, all cells adhered firmly to the substratum. The appearance of attached cells was characteristic; the spreading of cells to the substratum was retarded and almost all the cells were spherical with flattened bottoms (Fig. 3c).

Differentiated properties of the colonies. Formation of the cartilage matrix was not inhibited in so far as cells proliferated to form colonies. Fig. 4 shows a cartilage colony with a piled-up central refractile portion (6) filled with metachromatic cartilage matrix, that developed in the culture containing $3 \mathrm{ng} / \mathrm{ml}$ of tunicamycin. We also observed that cells forming a floating colony were stuck together by a viscous intercellular matrix. 


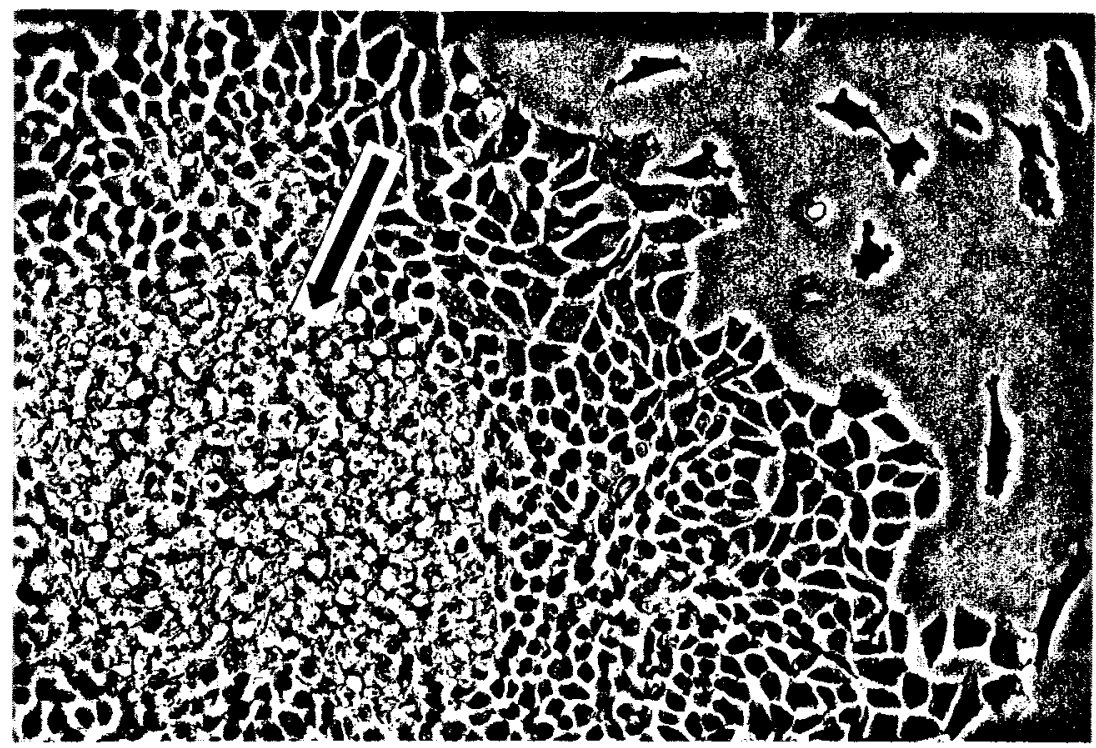

Fig. 4. A well-differentiated cartilage colony. Fifteen days of cultivation in medium containing $3 \mathrm{ng} / \mathrm{ml}$ of tunicamycin. The arrow indicates a central refractile portion. Phase-contrast micrograph. $\times 150$

\section{DISCUSSION}

The experiments (Fig. 1, Table 1) show that tunicamycin inhibits cell division at high dosage (more than $30 \mathrm{ng} / \mathrm{ml}$ ). It has been reported (11) that $50 \mathrm{ng} / \mathrm{ml}$ of tunicamycin inhibits the incorporation of D-mannose, up to $91 \%$, without any remarkable effect on the incorporation of L-leucine in chick embryo fibroblasts. Accordingly, retardation of the de novo synthesis of $\mathrm{N}$-glycosidically linked oligosaccharides, rich in mannose, may be responsible for the inhibition of cell division in chick embryo chondrocytes.

The primary cultures of chick embryo chondrocytes are more sensitive to tunicamycin than are the other cell culture systems studied so far. Their growth is inhibited by lower doses of the drug, than are various mammalian cell strains, such as mouse 3 T3 and NRK cells $(4,9)$ or human FL cells (unpublished data). The FL cells require a 10-100 fold higher concentration of tunicamycin for inhibition of cell division.

Why do such differences in tunicamycin sensitivity come about? We speculate that to adapt freshly isolated tissue cells to in vitro environments, the de novo synthesis of some molecule(s) that possesses the carbohydrate moieties sensitive to tunicamycin, is necessary; whereas for cells of established lines, the synthesis of such a molecule(s) may not be a prerequisite.

The important point is that the blockage of cell division by tunicamycin is completely reversible, and there are no serious lesions on cellular functions (Table 1). The higher efficiency of colony formation may be explained, at least in part, by the $100 \%$ adhesion of the inoculated cells to the substratum at concentrations higher than $30 \mathrm{ng} / \mathrm{ml}$ (Table 2). The tendency for synchronous cell division among colonies and the resulting uniformity of colony size (Fig. 2), suggests that tunicamycin at these concentrations interferes with the cell cycle at some point, and that cells under 
tunicamycin blockage are accumulating in a specific phase of the cell cycle.

Tunicamycin inhibits the adhesion and spreading of cells on the substratum at low doses (less than $3 \mathrm{ng} / \mathrm{ml}$ ) with no notable effects on cell division (Fig. 1) and the expression of differentiative functions (Fig. 4). Dessau et al. (2) suggested that chondrocytes attached directly to Type -II collagen filaments, synthesized immediately after incubation. The reduction in cell adhesion caused by tunicamycin may be due to the retardation of maturation of Type-II collagen from a precursor defective in its carbohydrate moiety, as suggested by the maturation of Type-I collagen (3).

In contrast to the dose dependent inhibition of adhesion at low concentrations, all the cells adhered to the substratum at concentrations higher than $30 \mathrm{ng} / \mathrm{ml}$. The discreteness of the dose response and the differences in the morphological appearance of the cells suggest that the mechanism of adhesion at high concentrations is entirely different from that at the low concentrations.

It should be remembered that $30 \mathrm{ng} / \mathrm{ml}$ of tunicamycin is the same concentration that inhibits cell division. At this concentration, chick embryo chondrocytes are considered "dormant" in regard to both cell division and adhesive behavior.

Acknowledgements. Thanks are due to Professor T.S. Okada, Kyoto University, for his kind aid in revising the manuscript, and also to Dr. Hisao Honda, Kanebo Institute for Cancer Research, for his discussion.

\section{REFERENCES}

1. Cahn, R.D., H.G. Coon and M.B. CAHN. Cell culture and cloning techniques. in Methods in Developmental Biology, ed. F.N. Wilt and N.K. Wessells, Crowell, New York, pp. 493-530, 1968

2. Dessau, W., J. Sasse, R. Timpl and K. von Der Mark. Role of fibronectin and collagen Type-I and -II in chondrocytic differentiation in vitro. Ann. N.Y. Acad. Sci. 312, 404-409, 1978

3. Duksin, D. and P. Bornstein. Impaired conversion of procollagen to collagen by fibroblasts and bone treated with tunicamycin, an inhibitor of protein glycosylation. J. Biol. Chem. 252, 955-962, 1977

4. Duksin, D. and P. BoRnstern. Changes in surface properties of normal and transformed cells caused by tunicamycin, an inhibitor of protein glycosylation. Proc. Natl. Acad. Sci. U.S.A. 74, 3433-3437, 1977

5. Duksin, D., K. Holbrook, K. Williams and P. Bornstein. Cell surface morphology and adhesive properties of normal and virally transformed cells treated with tunicamycin, an inhibitor of protein glycosylation. Exp. Cell Res. 116, 153-165, 1978

6. EgUCHI, G. and T.S. OKADA. Ultrastructure of the differentiated cell colony derived from a singly isolated chondrocyte in in vitro culture. Develop. Growth Differ. 12, 297-312, 1971

7. HarT, G.W. and W.J. LenNarz. Effects of tunicamycin on the biosynthesis of glycosaminoglycans by embryonic chick cornea. J. Biol. Chem. 253, 5795-5801, 1978

8. Horwitz, A.L. and A. Dorfman. The growth of cartilage cells in soft agar and liquid suspension. J. Cell Biol. 45, 434-438, 1970

9. Kohno, K., A. Hiragun, H. Mitsui, A. Takatsuki and G. Tamura. Effect of tunicamycin on cell growth and morphology of nontransformed and transformed cell lines. Agric. Biol. Chem. (in press)

10. Moscona, A.A. (ed.) The Cell Surface in Development. John Wiley \& Sons, New York, 1974

11. Olden, K., R.M. Pratt and K.M. Yamada. Role of carbohydrates in protein secretion and turnover: Effects of tunicamycin on the major cell surface glycoprotein of chick embryo fibroblasts. Cell 13, 461-473, 1978 
12. Poste, G. and G.L. Nicolson. (ed.) Cell Surface Reviews. Vol. 3. Dynamic Aspects of Cell Surface Organization. North-Holland, Amsterdam, 1977

13. Struck, D.K. and W.J. Lennarz. Evidence for the participation of saccharide-lipids in the synthesis of the oligosaccharide chain of ovalbumin. J. Biol. Chem. 252, 1007-1013, 1977

14. Struck, D.K., P.B. Siuta, M.D. Lane and W.J. Lennarz. Effect of tunicamycin on the secretion of serum proteins by primary cultures of rat and chick hepatocytes. J. Biol. Chem. 253, 5332-5337, 1978

15. Takatsuki, A., K. Kawamura, M. Okina, Y. Kodama, T. Ito and G. Tamura. The structure of tunicamycin. Agric. Biol. Chem. 41, 2307-2309, 1977

16. TAKATsuki, A., K. Kohno and G. TAmURA. Inhibition of biosynthesis of polyisoprenol sugar in chick embryo microsomes by tunicamycin. Agric. Biol. Chem. 39, 2089-2091, 1975

17. TKaCZ, J.S. and J.O. LAMPEN. Tunicamycin inhibition of polyisoprenyl N-acetylglucosaminyl pyrophosphate formation in calf-liver microsomes. Biochem. Biophys. Res. Commun. 65, 248257, 1975

18. Watanabe, K. Changes in the capacity for clonal growth and differentiation in vitro of the vertebral cartilage cells with embryonic development. 1. Culture in the standard medium. Develop. Growth Differ. 12, 79-88, 1970

19. Watanabe, K. Changes in the capacity for clonal growth and differentiation in vitro of the vertebral cartilage cells with embryonic development. 2. Vitalizing effect of conditioned medium on the cells of younger embryos. Develop. Growth Differ. 13, 107-118, 1971

20. Watanabe, M. and T.S. Okada. The relationship between cell-substrate adhesiveness and cell growth: A study on chondrocytes cultured in vitro with conditioned medium. Develop. Growth Differ. 17, 51-59, 1975

21. Yamada, K.M. and K. Olden. Fibronectins-adhesive glycoproteins of cell surface and blood. Nature 275, 179-184, 1978 